\title{
Annals of Neonatology Journal
}

\section{Original Article}

\section{The Frequency, Types and Risk Factors of Congenital Anomalies in a}

\section{Tertiary Neonatal Intensive Care Unit (A hospital based study)}

Amira M. Shalaby ${ }^{* 1}$ and Amira F. EL-Gazzar ${ }^{2}$

DOI: $10.21608 / a n j .2020 .53883 .1015$

*Correspondence: Lecturer of Pediatrics, Faculty of Medicine, Assiut University, Egypt.

Email: amirashalaby@aun.edu.eg,

Full list of author information is available at the end of the article

\section{Abstract}

Background: Congenital anomalies (CA) are common causes of infant's and childhood deaths and disability. Objectives: The aim of the study is to determine the frequency, describe the types and risk factors of congenital anomalies among newborns admitted to Neonatal Intensive Care Unit (NICU) of Assiut University Children's Hospital. Study design: It is a prospective observational study (analytic cross sectional study) was performed and screening of the newborns admitted at NICU of Assiut University Children's Hospital (for 6 months) during the period from $1^{\text {st }}$ December 2017 to $31^{\text {st }}$ May 2018. The sample included 346 newborns, 173 cases and 173 controls. We collected data using a record checklist and an interviewing questionnaire. Results: There were significant differences between cases and controls concerning gestational age $(\mathrm{P}=0.001)$, single or multiple babies $(\mathrm{P}=0.002)$, residence $(\mathrm{P}=0.001)$, consanguineous marriage $(\mathrm{P}=0.01)$ and family history of unfavorable outcome $(\mathrm{P}=0.001)$. We also found that the most common type of congenital anomalies was gastrointestinal anomalies 63 cases $(36.4 \%)$ with tracheoesophageal fistula 17 cases $(27 \%)$ being the most common GIT anomalies. Then the musculoskeletal anomalies being the second common anomalies $14.5 \%$ with diaphragmatic hernia 10 cases being the most common in musculoskeletal anomalies followed by other anomalies (22 multiple and 1Conjoined Twins) 23 cases (13.3\%) followed by cardiovascular anomalies 22 cases (12.7\%), followed by CNS anomalies 18 cases (10\%). Conclusions: The frequency of congenital anomalies was 22.97\%. The most common anomalies were gastrointestinal anomalies (GIT), musculoskeletal anomalies, multiple anomalies and cardiovascular system anomalies. The risk factors were consanguineous marriage, positive family history, urban areas, full-term and singleton pregnancies. Key words: Congenital anomalies (CA), Risk factors, frequency, types 


\section{Introduction}

Congenital anomalies or birth defects can be classified according to the World Health Organization (WHO) as functional or structural anomalies. They can be detected during intrauterine life, at birth or later in infancy [1]. Congenital anomalies are common causes of infant and childhood mortality and morbidity. The World Health Organization (WHO) declared that about 303,000 newborns die yearly all over the world within 30 days from birth because of congenital anomalies [2]. Most of these anomalies occur in middle and lowincome countries [3]. In Egypt, the frequency of congenital anomalies was 20/1000 live births in 2009 [4]. The frequency of $\mathrm{CA}$ among newborns in Assuit University Children's Hospital was $2.06 \%$ in 2007 [5]. Major congenital anomalies cause more costly health care than other hospitalizations [6]. Congenital anomalies may be inherited or secondary to environmental factor or multifactorial [6]. It was also found that more than half of spontaneous abortions are because of chromosomal abnormalities [7]. The critical period in the pathogenesis of congenital anomalies is the first 4 weeks of development, the first 2 weeks which is associated with major congenital anomalies and also severe damage may cause death of the conception, after 2 weeks of development the exposure to teratogen is associated with minor congenital anomalies as epicanthic fold, growth restriction or abnormalities in the phenogenesis $[8,9]$.

The aim of the work: is to determine the frequency, describe the types and risk factors of congenital anomalies among newborns admitted to Neonatal Intensive Care Unit (NICU) in one tertiary care center.

\section{Methods}

Study design: This is a prospective analytic cross sectional study was carried out in the neonatal intensive care unit. It is a tertiary care center. The center 
provides multi-specialist care and serves as a major referral center in Upper Egypt for hospitals within and outside the city. The study was done during the period of 6 months from December 2017 to May 2018.

Patients: All the babies admitted to the hospital with congenital anomalies during this period were included. All stillbirths were excluded from this study. The sample was 346 newborns, 173 cases and 173 controls. For each case, a detailed perinatal, maternal and family history was obtained by interviewing questionnaire. Diagnosis of congenital anomalies was based on clinical evaluation of newborn babies by the neonatologist and other appropriate investigations such as radiography, ultrasonography, echocardiography and chromosomal analysis etc...

Classification of anomalies is done by systems according to WHO international classification of diseases (ICD10) [10]. Data was entered into excel data sheet and appropriate statistical analysis was performed. The frequency was calculated by dividing the number of $\mathrm{CA}$ during the 6 months (173) by the total number of admission during this period $(753) \times 100$ [11].

\section{Statistical analysis}

Data were analyzed using (SPSS Statistics for Windows, Version 21.0, NY). Descriptive analysis of the whole sample; where data were expressed as mean values and standard deviations for quantitative variables, and numbers and frequencies for qualitative variables. Bivariate analysis was performed to assess associations between various independent variables and the dependent variable (presence of congenital anomalies), chi-square was used to compare the difference in distribution of frequencies among different groups and if number inside the cell was small we used Fisher's Exact Test. Independent sample T-test was used to compare the difference in means among different groups. A significant $\mathrm{p}$ value was 
considered when it less than or equal 0.05 .

\section{Ethics approval and consent to} participate: This study was approved by the head of the University Children's Hospital, the head of the NICU and by the Ethical Committee for Scientific Research of the Faculty of Medicine, Assuit University. (The approval ID of the ethics committee IRB no: 17300493)

An informed written consent was obtained from all parents' participants included in the study.

\section{Results}

Our study included 346 newborns, 173 cases and 173 controls, of the cases there were 138 full-term and 35 preterm, 109 were males and 64 were females. There were a significant difference between cases and controls concerning gestational age, single or multiple babies, residence, consanguineous marriage and family history of unfavorable outcome. There is an increased risk of congenital anomalies in full-term babies, single babies, urban areas, consanguineous marriage and family history of unfavorable outcome (previous congenital anomalies, stillbirth, and previous abortions) as shown in table (1). We found the frequency of congenital anomalies was $22.97 \%$ as shown in figure (1). We also found that the most common type of congenital anomalies was gastrointestinal anomalies in 63 cases (36.4\%) with tracheoesophageal fistula was present in 17 cases $(27 \%)$ being the most common among GIT anomalies. Then the musculoskeletal anomalies being the second common anomalies in $14.5 \%$ with diaphragmatic hernia was present in 10 cases being the most common in musculoskeletal anomalies followed by other anomalies (22 multiple and 1conjoined twin as shown in (fig.3) 23cases (13.3\%) followed by cardiovascular anomalies 22cases (12.7\%) with PDA was the most common, followed by CNS 18 cases (10\%) anomalies followed by urinary system anomalies 15 cases (9\%) 
followed by respiratory system anomalies 4 cases followed by chromosomal anomalies 2 cases and eye, ear, face and neck anomalies only one case being the least common as shown in table (2)

\section{Discussion}

The frequency of congenital anomalies among studied newborns was $22.97 \%$. This was in agreement with Sankar et al., 2017[12] who found the frequency of congenital anomalies among stillbirth was $15.3 \%$ in a study in a tertiary care hospital in Kerala India. This was in agreement with Adeboye et al., 2016[13] who found the frequency of CA was $111 / 1000$ in a study in a tertiary medical center, located in Bida in Niger State. This also was in agreement with Jangra et al., 2014 [14] who found a high frequency of CA about $30.18 \%$ in a study in a Pediatric Surgery Department of a Tertiary Care Institute of North India. Although the result of this study was not in accordance with Kurdi et al., 2019
[15] who found that the frequency of congenital anomalies was about $4.12 \%$ in tertiary care center in Riyadh, Saudi Arabia.

Bhide and Kar, 2018 [16] found that congenital anomalies pooled a frequency about $1.8 \%$ in India, this high frequency rate in this study, can be explained by that the NICU of Assiut University Children's Hospital is a tertiary care center that receive cases from different areas allover Upper Egypt, but actually the rate may be more because cases of congenital anomalies that didn't need admission were excluded from the study. The most common congenital anomalies in this study were GIT anomalies $36.4 \%$. The predominant defect was tracheoesophageal fistula (17) cases followed by musculoskeletal anomalies $14.5 \%$. This is in agreement with Abdou et al., 2019 [17] who found that the GIT anomalies were the most common anomalies in a study done in the Pediatric University Hospital Alexandria Egypt during the period November 2015-May 
2016. This is in agreement with Takai et al., 2019 [18] who found that the most common affected system with congenital anomalies was gastrointestinal system in a study in the Department of Obstetrics and Gynecology and the Department of Pediatrics (Special Care Baby Unit), AKTH, Kano India. This is against Oluwafemi and Abiodun, 2019 [19] who found that CNS is the most common affected system by CA in a study, done at a level II Neonatal Intensive Care Unit of the Mother and Child Hospital Akure (MCHA) in Ondo State, South western Nigeria. This is also against Giang et al., 2019 [20] who found that the most common type of CA being congenital heart defects in central Vietnam. This is against Ameen et al., 2018 [21] that reported CNS anomalies were the most common in the maternity teaching hospital, Erbil city, Iraq. This is against Ecwochi et al., 2018 [22] who found that is the most affected system with congenital anomalies was Musculoskeletal system. This is also against Abou EL-Ella et al., 2018[23] who found that the most common affected system was musculoskeletal system in a study in pediatric genetics clinic in the pediatric department-Menoufia university hospital. It was found that chromosomal anomalies - were found in 2cases- and eye, ear, face and neck anomalies- were present in only one case- being the least common. This is against Abou El-Ella et al., 2018[23] who found that eye, ear, face and neck anomalies were the 2nd most common system affected but these results were in agreement with his finding that chromosomal anomalies were only $7 \%$. This was against Shawky and Sadik, 2011[4] who found that the 2nd most common system affected was chromosomal anomalies and the eye, ear, face and neck anomalies were the seventh system affected. Concerning the associated factors with CA in this study it was found that congenital anomalies were significantly higher among consanguineous marriage (57.3\%) than 
non-consanguineous. This is in agreement with Abdou et al., 2019 [19] who found that $47 \%$ of cases with CA versus $38 \%$ of controls have positive consanguinity history. This is in agreement with Sunitha et al., 2016 [24] who found that consanguinity was a risk factor for CA. This is in agreement with kheir and Yassin, 2015 [25] who found consanguineous marriage in $54 \%$ of cases with CA. This is against Taye et al., 2018 [26] who found consanguinity in $4.8 \%$ of cases of congenital anomalies. This is against Rostazemadeh et al., 2017 [27] who found (25\%) of the newborns with CA were from consanguineous marriages, while $(75 \%)$ were from nonconsanguineous marriages in a study in Shahid-Madani hospital in Northwest of Iran. This study found that positive family history of unfavorable outcome was significantly associated with congenital anomalies. This is in agreement with Ameen et al., 2018 [21] who found that previous congenital anomalies were associated with high risk of congenital anomalies. This is against Faal et al., 2018 [28] who found that only one affected case was associated with positive family history of congenital anomalies. This study also found that the CA were significantly common with urban than rural area. This may be due to environmental pollution in the urban areas which is more than rural areas that can be a risk factor for CA. This is in agreement with Li et al., 2019 [29] who found CA of the kidney and urinary tract were more common in urban areas than in rural areas. This is in agreement with Mombo et al., 2017 [30] who found that $\mathrm{CA}$ has a lower incidence with rural areas than urban areas. This is in agreement with Xia et al., 2015[31] who found the incidence of $\mathrm{CA}$ is lower in rural areas than urban areas. This is against Genowska et al., 2016 [32] who found the mortality rates due to CA were significantly higher in rural areas than urban areas. This is against Cui et al., 2016 [33] who found death rates due to CA was more in rural areas than urban 
areas. This study also found that CA were significantly higher with full-term newborns than preterm newborns. This can be explained by the higher death rates of preterm babies than full-term babies so there was no enough time for referral and diagnosis of CA in preterm cases. This is in agreement with Padmanabhan et al., 2019 [34] who found $77 \%$ of malformed babies were full-term. This is in agreement with Bairoliya, and Fink, 2018 [35] who found that CA represented about $58.1 \%$ of causes of full-term mortality in early neonatal period. This is in agreement with Fontoura and Cardoso, 2014 [36] who found higher frequency of CA with full-term babies. This against Faal et al., 2018 [28] who found higher frequency of premature and LBW newborns in cases with CA was present. This is against Mekonen et al., 2016 [37] who found that CA was higher with low birth weight newborn. This study found that there was increased frequency of CA with singleton pregnancies versus twin pregnancies.
This can be explained by the increased survival of singleton babies versus twin babies in our community. This is against Best and Rankin, 2015 [38] who found increased rate of congenital heart disease among twins than singletons. This is against Menasinkai et al., 2013 [39] who found higher incidence of CA among same sex twins than singletons.

Limitations of the study: The study has included mostly the major congenital anomalies who needed hospital admission. It represents the congenital anomalies in one tertiary care center not all the centers in Upper Egypt.

\section{Conclusions}

The frequency of congenital anomalies was $22.97 \%$. The most common anomalies were gastrointestinal anomalies (GIT), musculoskeletal anomalies, multiple anomalies and cardiovascular system anomalies. The risk factors were consanguineous marriage, positive family history, urban 
areas, full-term and singleton pregnancies.

We have to intensify the importance of antenatal care and the postnatal screening for CA. We have to improve the awareness in our community about the drawbacks of consanguineous marriage and the importance of genetic counseling in families with positive history. We also recommend further studies with longer duration to discover more congenital anomalies and their preventable causes.

\section{List of Abbreviations:}

ASD: Atrial Septal Defect

CA: congenital anomalies

CHPS: Congenital Hypertrophic Pyloric

Stenosis

CNS: central nervous system

GIT: Gastrointestinal tract

ICD10: International Classification of Diseases 10

NICU: Neonatal Intensive Care Unit

PDA: Patent Ductus Arteriosus

TGA: Transposition of great arteries

TOF: Tetralogy of Fallot

VSD: Ventricular Septal Defect

WHO: World Health Organization

\section{Acknowledgements}

To all the staff members, assistant lecturers, residents and nursing team of the NICU.

\section{Author's contributions}

AS: designing the work, Data acquisition, interpretation of results and writing the manuscript. AE: Statistical analysis of the collected data and revision of the work. All authors have read and approved the submitted manuscript

\section{Conflict of interest}

Authors declare they have no conflict of interest

\section{Author's details}

${ }^{1}$ Lectuer of Pediatrics, Assiut University Children's Hospital, Faculty of medicine Assiut University, Egypt

${ }^{2}$ Lecturer of Public Health and Community Medicine, Faculty of Medicine, Assiut University, Assiut, Egypt

Date received: $2^{\text {nd }}$ December 2020, accepted $26^{\text {th }}$ December 2020.

\section{References}

1. DeSilva M, Munoz FM, Mcmillan M, Kawai AT, Marshall H, Macartney $\mathrm{KK}$,et al and The Brighton Collaboration Congenital Anomalies Working Group . Congenital anomalies: Case definition and guidelines for data collection, analysis, and presentation of immunization safety data. Vaccine. 2016 
Dec 1; 34(49): 6015-6026. Available from: doi: 10. 1016/ j.vaccine. 2016.03. 047

2. World Health Organization. Congenital anomalies. Geneva: WHO. 2016 [Google Scholar]

3. Sitkin NA, Ozgediz D, Donkor P, Farmer DL Congenital anomalies in lowand middle-income .countries: the unborn child of global surgery. World J Surg. 2015; 39:36-40

4. Shawky RM, Sadik DI Congenital malformations prevalent among Egyptian children and associated risk factors. Egyptian Journal of Medical Human Genetics.2011 May; 12(1):6978.Available from: https: // doi.org/ 10.1016/ j. ejmhg. 2011.02.016

5. Mohammed YA, Shawky RM, Soliman AA, Ahmed MM. Chromosomal study in newborn infants with congenital anomalies in Assuit University Hospital: cross sectional study. EJMHG.2011; 12: 79-90

6. Feldkamp ML, Carey JC, Byrne JLB, Krikov S, Botto LD. Etiology and clinical presentation of birth defects: population based study. BMJ. 2017; 357: j2249.
7. Zhang Y-X, Zhang Y-P, Gu Y, Guan FJ, Li S-L, Xie J-S, et al. Genetic analysis of first-trimester miscarriages with a combination of cytogenetic karyotyping, microsatellite genotyping and array CGH. Clin Genet. 2009; 75: 133-140. DOI: 10.1111/ j.13990004.2008.01131.x

8. Dutta S. Human teratogens and their effects: a critical evaluation. IJIRR. $2015 ; 2$ (3):525-536

9. Gilbert-Barness E. Teratogenic Causes of Malformations Ann Clin Lab Sci Spring. 2010; 40: 2 99-114

10. International statistical classification of diseases and related health problems, 10th revision. Geneva: World Health Organization; 2010. Available from: (http://apps.who.int/classifications/icd1 0/browse/2010/enexternal icon, . accessed 11 February 2014).

11. Centers for Disease Control and Prevention: Principles of Epidemiology in Public Health Practice, Third Edition - An Introduction to Applied Epidemiology and Biostatistics. Available from: https:// www.cdc.gov/ csels/ dsepd/ ss1978/lesson3/section2.html 
12. Sankar V, Uma T, George S, Vasu A, Kumar S, Santhoshkumar A, et al. Pattern of congenital abnormalities in a tertiary hospital and its impact on neonatal mortality. Indian Journal of Child Health. 2017; (4):599-02. Available from: https:// atharvapub.net/ IJCH/ article/view/374

13. Adeboye M, Abdulkadir MB, Adegboye OA, Saka AO, Oladele PD, Oladele DM, et al. A prospective study of spectrum, risk factors and immediate outcome of congenital anomalies in Bida, North Central Nigeria. Ann Med Health Sci Res 2016; 6:380-4.

14. Jangra B, Singh M, Rattan KN, Kadian YS, Kaur A. Congenital anomalies in paediatric surgery in North India. Afr $\mathbf{J}$ Paediatr Surg [serial online] 2014 [cited 2020 Feb 3]; 11: 39-43. Available from: http:/ /www. afrjpaedsurg.org/ text. asp? 2014/ 11/1/39/129214

15. Kurdi AM, Majeed-Saidan MA, Al Rakaf MS, AlHashem AM, Botto LD, Baaqeel HS, et al. Congenital anomalies and associated risk factors in a Saudi population: a cohort study from pregnancy to age 2 years. BMJ.2019; 9 (9) Available from: http:// dx.doi.org/10.1136/bmjopen-2018026351

16. Bhide P, Kar A A national estimate of the birth frequency of congenital anomalies in India: systematic review and meta-analysis. BMC Pediatr. 2018 May 25; 18 (1):175. doi: 10.1186/ s12887 -018-1149-0.

17. Abdou, M.S.M., Sherif, A.A.R., Wahdan, I.M.H. Ashour KSE. Pattern and risk factors of congenital anomalies in a pediatric university hospital, Alexandria, Egypt. J. Egypt. Public. Health. Assoc. 2019; 94 (3). doi: 10. 1186/ s42506-018-0004-3

18. Takai I U, Gaya S A, Sheu M T, Abdulsalam M Pattern of birth defects at a university teaching hospital in Northern Nigeria: Retrospective review over a decade. Tropical Journal of Obstetrics and Gynaecology. 2019; 36(2): 287-292

19. Oluwafemi RO, Abiodun MT. Incidence, spectrum and outcome of congenital anomalies seen in a neonatal intensive care unit in Southern Nigeria. Niger Postgrad Med J.2019 Oct-Dec; 26(4):239-243. doi: 10.4103/npmj.npmj_77_19. 
20. Giang HTN, Pozza SB-D, Ulrich S, Linh LK, Tran HT. Frequency and Pattern of Congenital Anomalies in a Tertiary Hospital in Central Vietnam, Journal of Tropical Pediatrics. 2019; $66 \quad$ (2):187-193.Available from: https:

//doi.org/10.1093/tropej/fmz050

21. Ameen SK, Alalaf SK, Shabila NP. Pattern of congenital anomalies at birth and their correlations with maternal characteristics in the maternity teaching hospital, Erbil city, Iraq. BMC Pregnancy Childbirth. 2018; 18(1):501. doi: 10.1186/ s12884-018-2141-2

22. Ekwochi U, Asinobi IN, Osuorah DCI, Ndu IK, Ifediora C, Amadi OF et al. Pattern of Congenital Anomalies in Newborn: A 4-Year Surveillance of Newborns Delivered in a Tertiary Healthcare Facility in the South-East Nigeria, Journal of Tropical Pediatrics. August 2018; 64(4): 304-311. Available from: https:

//doi.org/10.1093/tropej/fmx067.

23. AbouEl-Ella SS, Tawfik MA, Abo El-

Fotoh WMM, Elbadawi MA, Study of congenital malformations in infants and children in Menoufia governorate,
Egypt. Egyptian Journal of Medical Human Genetics.2018; 19(4): 359-365.

24. Sunitha T, Prasoonaa KR, Kumarib TM, Srinadha B, Deepika MLN, Aruna R et al. Risk factors for congenital anomalies in high risk pregnant women: A large study from South India. Egyptian Journal of Medical Human Genetics. January 2017; 18(1):79-85. Available from: http:// dx.doi.org/ 10.1016/ j.ejmhg. 2016.04.001

25. Kheir A.E.M and Yassin A.A.Y.A. Pattern of Congenital Anomalies and Validation of Antenatal Diagnosis in a tertiary neonatal unit in Sudan. Journal of International Research in Medical and Pharmaceutical Sciences. 2016; 6(3): 115-120.

26. Taye, M, Afework, M, Fantaye, W, Diro E \& Worku A. Factors associated with congenital anomalies in Addis Ababa and the Amhara Region, Ethiopia: a case-control study. BMC Pediatr.2018; 18 (142) doi: 10.1186/s12887- 018$1096-9$

27. Rostamizadeh L, Bahavarnia SR, Gholami R. Alteration in incidence and pattern of congenital anomalies among newborns during one decade in Azarshahr, Northwest of Iran. 
International Journal of Epidemiologic

Research.2017; 4(1): 37-43.

28. Faal G, Abbasi R, Bijari B. The Frequency of Major Congenital Anomalies Among Live Births in Birjand. Iran, Mod Care J. 2018; 15 (2): e81084. doi: 10. 5812/ modernc.81084.

29. Li ZY, Chen YM, Qiu LQ, Chen DQ, $\mathrm{Hu} \mathrm{CG}, \mathrm{Xu} \mathrm{JY}$,et al. Frequency, types, and malformations in congenital anomalies of the kidney and urinary tract in newborns: a retrospective hospitalbased study. Ital J Pediatr. 2019; 45 (1): 50. doi: 10.1186/s13052-019-0635-9. PMID: 30999930; PMCID: PMC 6472003.

30. Mombo LE, Yangawagou-Eyeghe LM, Mickala P, Moutélé J, Bah TS, Tchelougou D, et al. Patterns and risk factors of birth defects in rural areas of south-eastern Gabon.Congenit Anom (Kyoto). May 2017; 57(3): 79-82. doi: 10.1111/ cga.12201.

31. Xia L, Sun L, Wang X, Yao M, Xu F, Cheng $\mathrm{G}$ et al. Changes in the Incidence of Congenital Anomalies in Henan Province, China, from 1997 to 2011. PLoS One. 2015; 10 (7):e0131874. doi: 10.1371/ journal. pone. 0131874
32. Genowska, A., Zalewska, M., Jamiołkowski, J., Stepaniak, U., Szpak, A., Maciorkowska, E. et al. Inequalities in mortality of infants under one year of age according to foetal causes and maternal age in rural and urban areas in Poland, 2004-2013. Ann Agric Environ Med.2016; 23(2): 285-291. https://doi.org/10.5604/12321966.12038 92

33. Cui H, He C, Kang L, Li Q, Miao L, Shen L, et al.Under 5 Years Child Mortality due to congenital anomalies. A retrospective study in Urban and Rural China in 1996-2013. American Journal of Preventive Medicine. 2016; 50 (5): p553-676, e123-e1 DOI: https:// doi.org/ 10.1016/ j. amepre. 2015.12.013

34. Padmanabhan R, Venkatasubramanian R, Heber A. Frequency and Pattern of Congenital Malformations among Neonates in a Medical College Hospital - A Retrospective Study. Int J Sci Stud.2019; 6 (12):28-31.

35. Bairoliya N, Fink G. Causes of death and infant mortality rates among full-term births in the United States between 2010 and 2012: An observational study. PLoS Med. 2018; 15(3): e1002531. https:// 
doi.org/ 10.1371/ journal. pmed. 1002531

36. Fontoura, F \& Cardoso, M. Association between congenital malformation and neonatal and maternal variables in neonatal units of a Northeast Brazilian city. Texto e Contexto Enfermagem. 2014; 23: 907-914. 10.1590/010407072014002320013.

37. Mekonen, H.K., Nigatu, B. \& Lamers, W.H. Birth weight by gestational age and congenital malformations in Northern Ethiopia. BMC Pregnancy
Childbirth. 2015; 15: 76. https:// doi.org/10.1186/s12884-015-0507-2

38. Best KE and Rankin J. Increased risk of congenital heart disease in twins in the North of England between 1998 and 2010. Heart. 2015; 101:1807-1812.Doi:

10.1136/ heartjnl-2015-307826

39. Menasinkai SB, Dakshayani KR, Chiniwar MA. Congenital malformations in multiple births. Int $\mathbf{J}$ Res Med Sci. 2013;1: xx-xx. DOI: 10.5455/2320-6012. Ijrms 20130809 
Table (1): Associated maternal and neonatal factors with congenital anomalies

\begin{tabular}{|c|c|c|c|c|c|c|}
\hline Associated factors & Item & Cases & $\%$ & Controls & $\%$ & $\mathrm{P}$ value \\
\hline \multirow[t]{2}{*}{ Gestational age } & Full term & 138 & 58.5 & 97 & 41.5 & \multirow[t]{2}{*}{$0.001 *$} \\
\hline & Preterm & 35 & 30.9 & 76 & 69.1 & \\
\hline \multirow[t]{2}{*}{ Gender } & Male & 109 & 47.6 & 120 & 52.4 & \multirow[t]{2}{*}{0.3} \\
\hline & Female & 64 & 53.8 & 53 & 47.6 & \\
\hline \multirow{2}{*}{$\begin{array}{l}\text { Single baby or } \\
\text { multiple }\end{array}$} & Single baby & 163 & 52.8 & 145 & 47.2 & \multirow[t]{2}{*}{$0.002 *$} \\
\hline & 2 or more & 10 & 26.3 & 28 & 73.7 & \\
\hline \multirow[t]{2}{*}{ Residence } & Rural & 83 & 38,6 & 131 & 61.4 & \multirow[t]{2}{*}{$0.001 *$} \\
\hline & Urban & 90 & 68.2 & 42 & 31.8 & \\
\hline \multirow{2}{*}{$\begin{array}{l}\text { Maternal age } \\
\text { (Years) }\end{array}$} & Less than 35 & 147 & 48.8 & 154 & 51.2 & \multirow[t]{2}{*}{0.2} \\
\hline & 35 or more & 26 & 57.8 & 19 & 42.2 & \\
\hline \multirow{2}{*}{$\begin{array}{l}\text { Drugs received } \S \\
\text { during pregnancy }\end{array}$} & Yes & 21 & 63.6 & 12 & 36.4 & \multirow[t]{2}{*}{0.09} \\
\hline & No & 152 & 48.4 & 161 & 51.6 & \\
\hline \multirow[t]{2}{*}{ Maternal disease $\S$} & Yes & 49 & 48.5 & 52 & 51.5 & \multirow[t]{2}{*}{0.2} \\
\hline & No & 124 & 50.6 & 121 & 49.4 & \\
\hline \multirow[t]{2}{*}{ Parity } & Primiparous & 41 & 47.1 & 46 & 52.9 & \multirow[t]{2}{*}{0.5} \\
\hline & Multiparous & 132 & 50.8 & 128 & 49.2 & \\
\hline \multirow[t]{2}{*}{ Previous abortion } & Yes & 48 & 49 & 50 & 51.0 & \multirow[t]{2}{*}{0.86} \\
\hline & No & 125 & 50 & 124 & 50.0 & \\
\hline \multirow{2}{*}{$\begin{array}{l}\text { Consanguineous } \\
\text { marriage }\end{array}$} & Yes & 86 & 57.3 & 63 & 42.7 & \multirow[t]{2}{*}{$0.01 *$} \\
\hline & No & 87 & 44.2 & 110 & 55.8 & \\
\hline \multirow{2}{*}{$\begin{array}{l}\text { Family history of } \\
\text { unfavorable } \\
\text { outcome }\end{array}$} & Positive & 67 & 52.8 & 12 & 47.2 & \\
\hline & Negative & 106 & 48.4 & 161 & 51.6 & $0.001 *$ \\
\hline
\end{tabular}

$* \mathrm{P}<.0 .05$ is considered statistically significant

$\S$ (common maternal diseases: Diabetes and preeclamia) (common maternal drug intake: antihypertensives, prenatal steroids and Levothyroxine) 
Table (2): Distribution of GIT anomalies in cases group

\begin{tabular}{|c|c|c|c|}
\hline System & Type & No. & Frequency $n=173$ \\
\hline \multirow{15}{*}{$\begin{array}{l}\text { Digestive system } \\
(63)\end{array}$} & Tracheoesophageal fistula (TOF) & 17 & 9.8 \\
\hline & Duodenal atresia & 10 & 5.8 \\
\hline & Imperforate anus & 8 & 4.62 \\
\hline & Megacolon & 8 & 4.62 \\
\hline & Jejunal atresia & 4 & 2.31 \\
\hline & Ileal atresia & 3 & 1.73 \\
\hline & Malrotaion & 3 & 1.73 \\
\hline & Gastric outlet obstruction & 2 & 1.16 \\
\hline & $\begin{array}{l}\text { Congenital hypertrophic pyloric } \\
\text { stenosis (CHPS) }\end{array}$ & 2 & 1.16 \\
\hline & Ranula & 1 & 0.58 \\
\hline & Annular pancreas & 1 & 0.58 \\
\hline & Rectal atresia & 1 & 0.58 \\
\hline & Anal stenosis & 1 & 0.58 \\
\hline & Combined & 1 & 0.58 \\
\hline & Colonic atresia & 1 & 0.58 \\
\hline
\end{tabular}


Table (3): Distribution of Musculoskeletal anomalies in cases group

\begin{tabular}{|llll|}
\hline System & Type & No. & Frequency n=173 \\
\hline Musculoskeletal & Achondroplasia & 3 & 1.73 \\
\cline { 2 - 4 } system (25) & Arthrogryposis & 1 & 0.58 \\
\cline { 2 - 4 } & Diaphragmatic hernia & 10 & 5.8 \\
\cline { 2 - 4 } & Cloacal exstrophy & 1 & 0.58 \\
\cline { 2 - 4 } & Bilateral hip dislocation & 1 & 0.58 \\
\cline { 2 - 4 } & Gastroschisis & 4 & 2.31 \\
\cline { 2 - 4 } & Exomphalos major & 2 & 1.16 \\
\cline { 2 - 4 } & Exomphalos minor & 1 & 0.58 \\
\cline { 2 - 4 } & Sacrococcygeal teratoma & 1 & 0.58 \\
\cline { 2 - 4 } & Prune belly syndrome & 1 & 0.58 \\
\hline
\end{tabular}

Table (4): Distribution of CVS anomalies in cases group

\begin{tabular}{|c|c|c|c|}
\hline System & Type & No. & Frequency $n=173$ \\
\hline \multirow{9}{*}{$\begin{array}{l}\text { Cardio-vascular } \\
\text { system (22) }\end{array}$} & Patent Ductus Arteriosus (PDA) & 6 & 3.47 \\
\hline & Atrial Septal Defect (ASD) & 5 & 2.9 \\
\hline & $\begin{array}{l}\text { Duct dependent cyanotic heart } \\
\text { disease }\end{array}$ & 3 & 1.73 \\
\hline & Complex & 3 & 1.73 \\
\hline & Ventricular septal defect (VSD) & 1 & 0.58 \\
\hline & Tricuspid atresia & 1 & 0.58 \\
\hline & Extreme fallot's tetralogy & 1 & 0.58 \\
\hline & $\begin{array}{l}\text { Total anomalous pulmonary venous } \\
\text { return (TAPVR) }\end{array}$ & 1 & 0.58 \\
\hline & $\begin{array}{l}\text { Transposition of great arteries } \\
\text { (TGA) }\end{array}$ & 1 & 0.58 \\
\hline
\end{tabular}


Table (5): Distribution of CNS anomalies in cases group

\begin{tabular}{|llll|}
\hline System & Type & No. & Frequency n=173 \\
\hline Central Nervous & Myelomeningocele & 6 & 3.47 \\
\cline { 2 - 4 } System (CNS) & Hydrocephalus & 5 & 2.89 \\
\cline { 2 - 4 } & Combined & 1 & 0.58 \\
\cline { 2 - 4 } & Encephalocele & 3 & 1.73 \\
\cline { 2 - 4 } & Meningocele & 3 & 1.73 \\
\hline
\end{tabular}

Table (6): Distribution of other anomalies in cases group

\begin{tabular}{|llll|}
\hline System & Type & No. & Frequency \\
Other congenital & & & \\
anomalies (23) & Multiple & 22 & 12.72 \\
\cline { 2 - 4 } & Conjoined Twins & 1 & 0.58 \\
\hline Urinary system (15) & Polycystic kidney & 5 & 2.89 \\
\cline { 2 - 4 } & Posterior urethral valve & 4 & 2.3 \\
\cline { 2 - 4 } & Bilateral hydronephrosis & 2 & 1.16 \\
\cline { 2 - 4 } & Multicystic dysplastic & 2 & 1.16 \\
& kidney disease & 1 & 0.58 \\
\cline { 2 - 4 } & Ectopia vescica & 0.58 \\
\cline { 2 - 4 } & Combined & 1 & 2.3 \\
\hline Eespiratory system & Bilateral choanal atresia & 4 & 1.16 \\
\hline Chromosomal (2) & Down syndrome & 2 & 0.58 \\
\hline Ear, eye, face neck (1) & Microphthalmos & 1 & \\
\hline & & & 1 \\
\hline
\end{tabular}




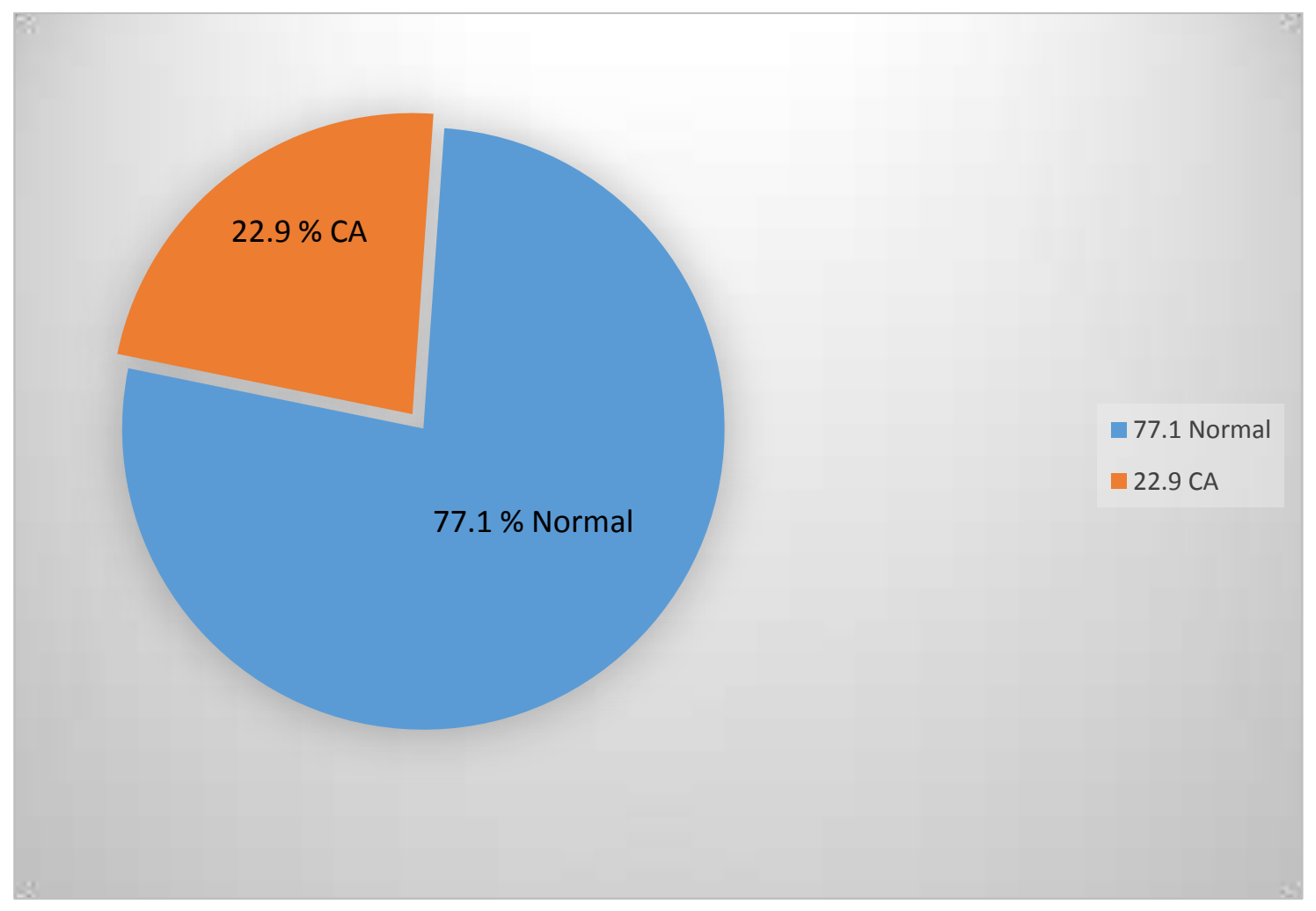

Fig (1): Frequency of congenital anomalies 


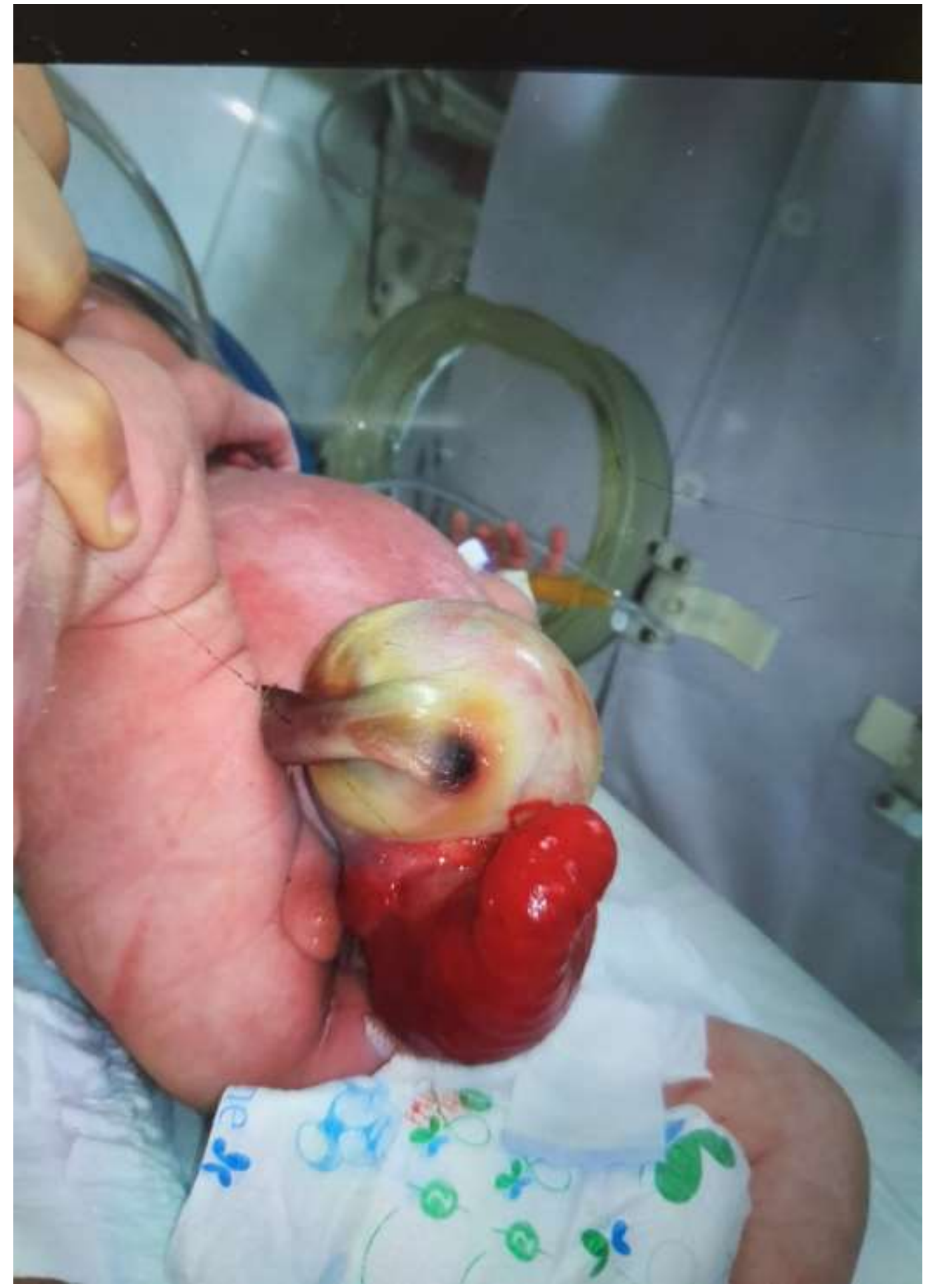

Fig. (2) Cloacal exstrophy 


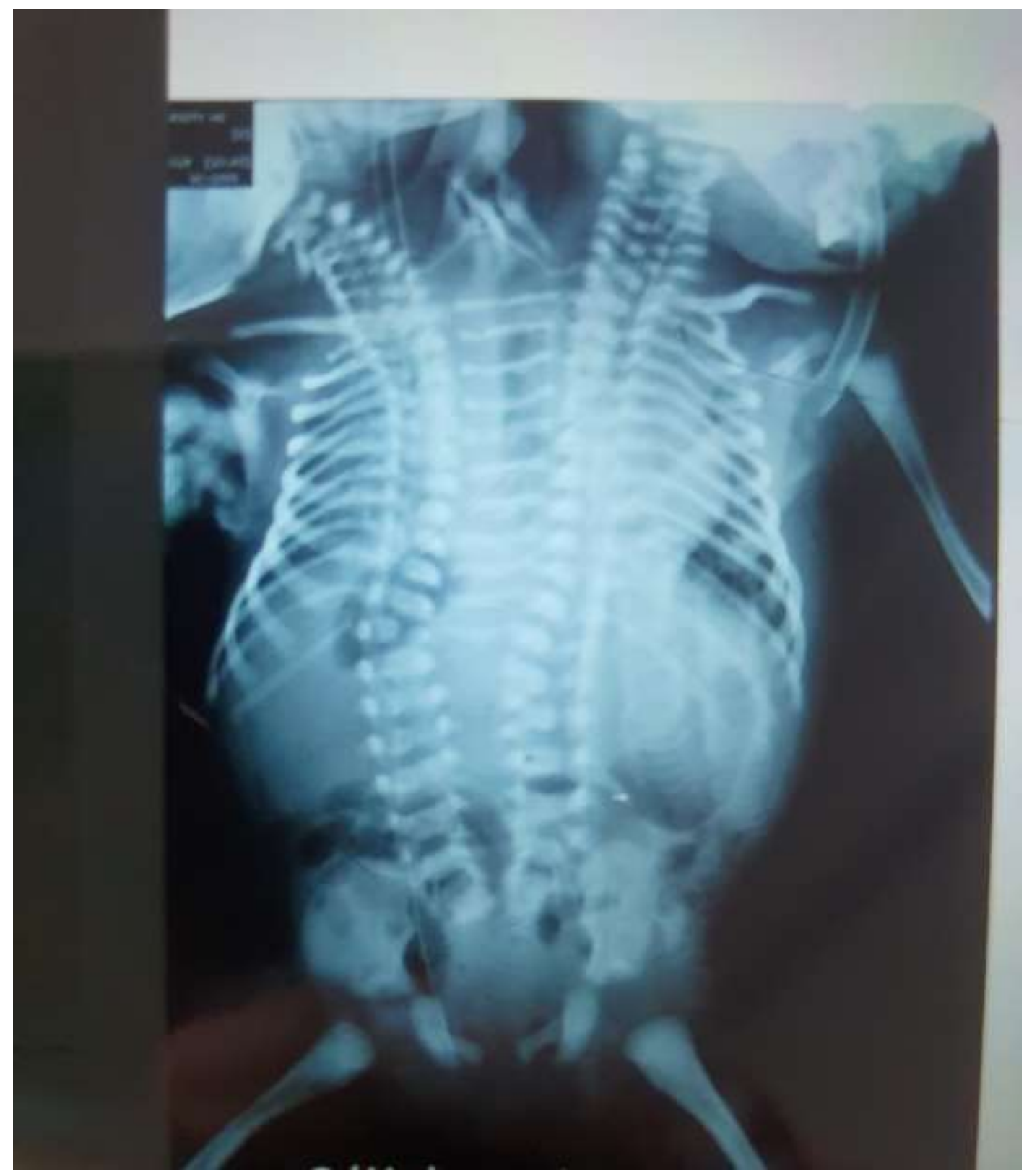

Fig. (3) X-ray of conjoined twins 


\section{The percent of congenital anomalies}

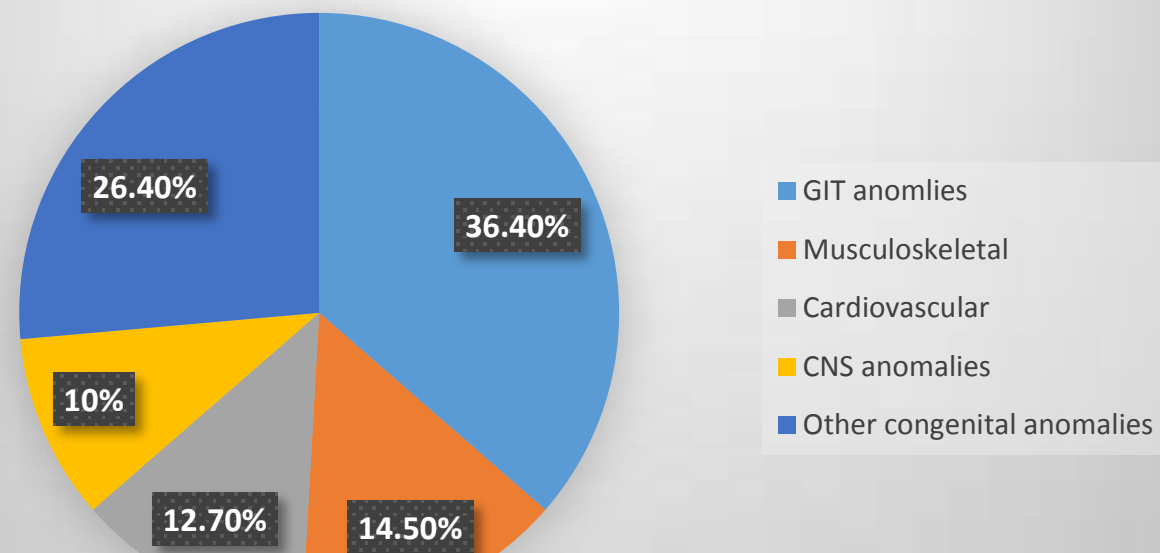

Fig. (4) The Percentage of congenital anomalies

Submit your next manuscript to Annals of Neonatology Journal and take full advantage of:

- Convenient online submission

- Thorough and rapid peer review

- No space constraints or color figure charges

- Immediate publication on acceptance

- No limit as regards tables or figures.

- Open Access research freely available for redistribution

Submit your manuscript at:

www.anj.journals.ekb.eg

Citation: Amira M. Shalaby; Amira F. EL-Gazzar. "The Frequency, Types and Risk Factors of Congenital Anomalies in a Tertiary Neonatal Intensive Care Unit (A hospital based study)". Annals of Neonatology Journal. 2021.3(1): 24-0 doi: 10.21608/anj.2020.53883.1015

Copyright: Amira M. Shalaby and Amira F. EL-Gazzar 2020. This article is an open access article distributed under the terms and conditions of the Creative Commons Attribution (CC-BY-NC-ND) license (4). 